\title{
EVALUASI PENERAPAN MANAJEMEN BERBASIS SEKOLAH (MBS) PADA SDN PASCA PENGHAPUSAN UNIT PELAKSANA TEKNIS (UPT)
}

\author{
Endang Iryani \\ Universitas MH Thamrin, Indonesia \\ endang1084@gmail.com
}

Received: 21 Februari 2020

Revised: 07 Maret 2020

Accepted: 13 Maret 2020

\begin{abstract}
Manajemen Berbasis Sekolah (MBS) merupakan pola penerapan pendidikan yang melibatkan segala unsur guna mencapai pendidikan yang ideal. MBS dicita-citakan oleh pemerintah menjadi suatu konsep yang mampu menjadikan pendidikan lebih baik. UPT adalah salah satu unit yang mengawasi pola penerapan MBS ditingkat Sekolah Dasar (SD), juga menjadi jembatan antara sekolah dan dinas pendidikan. Penelitian ini memiliki tujuan untuk menganalisa sejauhamana penerapan MBS pada SDN di kabupaten Tangerang pasca penghapusan UPT, dengan metode penelitian kualitatif pendekatan fenomenalogi, memotret penerapan MBS tersebut. hasil dari penelitian ini adalah ternyata penerapan MBS pada SDN di kabupaten Tangerang berjalan dengan baik. Dari hasil pengolahan data menunjukan bahwa dari lima variable skor yang didapat adalah 25.984 yang artinya penerapan MBS berjalan baik walaupun UPT telah dihilangkan. Sehingga penelitian ini bisa disimpulkan bahwa MBS telah berjalan baik pada SDN di kabupaten Tangerang walaupun UPT telah dihapus yang awalnya berperan sebagai jembatan antara sekolah dan dinas. Juga, keputusan pemerintah dalam penghapusan UPT bisa dikatakan tidak mempengaruhi peran sekolah dalam menyelenggarakan pendidikan menjadi lebih baik ditingkat Sekolah Dasar.
\end{abstract}

Keywords: Manajemen Berbasis Sekolah, MBS, Pendidikan, Sekolah Dasar, SD

(*) Corresponding Author:

Endang Iryani, endang1084@gmail.com, 081385544878

How to Cite: Iryani, Endang. (2020). Evaluasi Penerapan Manajemen Berbasis Sekolah (MBS) Pada SDN Pasca Penghapusan Unit Pelaksana Teknis (UPT). Research and Development Journal of Education, 6(2), 59-64.

\section{INTRODUCTION}

Manajemen Berbasis Sekolah atau School Based Management (MBS) merupakan pola penyesuaian Sumber Daya Manusia yang dilakukan secara mandiri oleh sekolah dengan melibatkan semua unsur kepentingan yang terkait dengan sekolah yang dilakukan secara langsung dalam proses pengambilan keputusan untuk memenuhi kebutuhan mutu sekolah. MBS ini memiliki tujuan untuk meningkatkan mutu pendidikan melalui otonomi sekolah dengan melibatkan berbagai unsur dalam menciptakan pola belajar serta output siswa yang bermutu. Sehingga sekolah menentukan sendiri apa yang perlu diajarkan, dan mengelola sumber daya yang ada untuk berinovasi. MBS juga memiliki potensi yang besar untuk menciptakan kepala sekolah, guru dan administrator yang professional. Dengan demikian, sekolah akan bersifat responsive terhadap kebutuhan masing-masing siswa dan masyarakat sekolah. (Komariah, 2015)

MBS ini muncul sebagai suatu jawaban atas adanya sentralistik kebijakan oleh pemerintah. Sebab, selama ini kebijakan sekolah mengikuti birokrasi pemerintah atau sentralistik, tanpa mempertimbangkan keadaan lingkungan sekolah, ketersediaan SDM 
sekolah dan kebutuhan peserta didik sekolah. Selain itu, MBS juga mencoba menjawab bahwa proses dalam pendidikan adalah hal penting bukannya fokus pada out put atau pencetakan saja. Hal ini yang sering dilupakan oleh lembaga pendidikan dan pemerintah yang konsen pada pendidikan bahwa memproduksi lebih utama dibandingkan proses produksi tersebut.

Dengan adanya otonomi sekolah, diharapkan bahwa sekolah mampu menciptakan sistem dan mekanisme pendidikan yang berkualitas dengan melibatkan berbagai unsur, seperti komite, murid, tokoh masyarakat dan pemerintah. Selama ini keterlibatan unsurunsur tersebut hanya terbatas pada financial tidak menyentuh pada kebijakan dalam penyusunan sistem dan mekanisme sekolah dalam dua belajar mengajar. Sehingga, pada MBS ini keaktifan pihak sekolah sangat di utamakan sebagai lokomotif dalam penyusun kebijakan.

Otonomi pada sistem MBS ini, juga diharapkan sebagai langkah meningkatkan partisipasi orang tua yang selama ini hanya menyerahkan anaknya kepada sekolah, mengeluarkan biaya adminsitrasi tanpa ada kepedulian dari sistem serta mekanisme sekolah untuk proses belajar anaknya. Konsep MBS, orang tua mampu menyumbangkan ide dan konsepnya terhadap sistem pendidikan di sekolah tempat anaknya belajar, sebab MBS lebih mengutamakan peningkatan prestasi siswa tidak hanya memunculkan prestasi siswa tanpa didukung dengan proses belajar yang baik.

Ideal MBS ini diharapkan mampu membangun pola pendidikan yang baik di Kabupaten Tangerang. Kabupaten yang terletak di Provinsi Banten dan berbatasan langsung dengan ibu kota Jakarta ini, menjadi wilayah pertumbuhan investor yang sangat tinggi terutama pada Property seperti Citra Raya, Sumarecon dan BSD City. Perusahaan besar properti ini membuat kota sendiri yang terpisah dengan penataan pemerintah kabupaten Tangerang. Dimana mereka memiliki sekolah salah satunya sebagai sarana pendidikan. Sehingga hal ini menjadikan pemerintah Kabupaten Tangerang harus menerapkan pola pendidikan yang mampu bersaing dengan sekolah-sekolah swasta favorit. Salah satunya adalah penerapan MBS di Sekolah Dasar Negeri (SDN).

Awal mulanya MBS ini dikontrol oleh Unit Pelaksana Teknis (UPT) Sekolah Dasar. UPT yang juga berperan sebagai supervisi ini memiliki peranan yang signifikan dalam Pendidikan sebagaimana dipahami bahwa supervisi merupakan kegiatan pengawasan dengan fokus utama melakukan penilaian keterlaksanaan kaidah-kaidah keilmuan dalam bentuk konsep dan teori yang melandasi pekerjaan profesional. Supervisi dilakukan dalam hubungan profesional antara pengawas dan orang-orang yang melaksanakan pekerjaan profesional, dalam penyelenggaraan sekolah hubungan profesional yang dimaksudkan misalnya antara pengawas dan guru (Satori, 2016). Sehingga penerapan MBS mampu dievaluasi setiap saat dan bisa dievaluasi setiap tahunnya. Akan tetapi 2018, terjadi kebijakan penghapusan UPT oleh Dinas Pendidikan kabupaten Tangerang. Hal ini bertujuan agar sekolah menjadi mandiri dalam mengelola sekolah dan langsung berhubungan dengan dinas pendidikan tanpa ada perantara. Tentunya ini akan menjadi hal baru bagi manajemen SDN di kabupaten Tangerang dan secara tidak langsung akan menyentuh pada penerapan MBS yang selama ini berjalan.

Berlandaskan dari itu, penulis tertarik untuk melakukan penelitian terhadap penerapan MBS pasca kebijakan penghapusan UPT di SDN kabupaten Tangerang, karena dampak penghapusan UPT ini secara tidak langsung akan memberikan dampak pada pola manajemen MBS di SDN. Sehingga penelitian ini bertujuan untuk mencari tahu sejauhmana dampak penerapan MBS pasca penghapusan UPT tersebut. karena sebelumnya UPT memiliki peran yang sangat signifikan bagi Sekolah Dasar dalam memberikan arahan dan masukan dalam pola manajemen sekolah, juga kemudahan sekolah dalam memberikan laporan administrasi ke Dinas Pendidikan. 


\section{METHODS}

Penelitian ini dilakukan selama empat bulan, dimulai pada bulan September sampai dengan Desember 2019. Penelitian ini menggunakan metode penelitian kualitatif dengan pendekatan Phenomologi. Dengan tehnik pengumpulan data menggunakan beberapa tehnik yaitu:

a. Survey instansional yakni kepada Dinas Pendidikan dan Sekolah Dasar

b. Melakukan kunjungan lapangan bila ada hal-hal yang dipandang perlu untuk dilakukan verifikasi

c. Diskusi, merupakan kegiatan untuk membahas dan mengkaji data dan temuan dalam monitoring dan evaluasi dengan para pemangku kepentingan.

d. Supervisi dan monitoring, yakni memberikan arah dan pemantauan mekanisme kinerja sekolah.

Adapun analisis data yang dilakukan adalah sesuai dengan tipe rancangan penelitian program, maka teknik analisa data mengikuti logika dari rancangan penelitian yang digunakan. Teknik analisis yang akan digunakan adalah:

1. Analisis deskriptif

Teknik analisis ini memberikan gambaran secara komprehensif dengan menyajikan berbagai data/informasi baik dari lapangan maupun dari instansional. Analisis ini disajikan dalam bentuk tabulasi, gambar dan verbal.

2. Analisis review dan evaluasi regulasi

Teknis analisis ini dilakukan untuk melakukan review dan studi mengenai berbagai regulasi, peraturan, persyaratan dan pelaksanaanya berkaitan dengan pendidikan.

3. Analisis faktor-faktor internal dan eksternal

Analisis ini dilakukan untuk melakukan identifikasi faktor-faktor internal dan eksternal dalam penelitian pendidikan sekolah dasar melalui variable MBS.

\section{RESULTS \& DISCUSSION}

Manajemen Berbasis Sekolah (MBS) bertujuan untuk meningkatkan kualitas pendidikan terutama di daerah, karena sekolah dan masyarakat tidak perlu menunggu perintah dari pusat, tetapi dapat mengembangkan suatu visi pendidikan yang sesuai dengan kondisi daerah dan melaksanakan visi pendidikan secara mandiri (Pratiwi, 2016). Gambaran ini memberikan pemahaman bahwa MBS merupakan konsep yang sangat bagus untuk mewujudkan Pendidikan berkualitas di Indonesia. Hal ini terbukti pada evaluasi Implementasi MBS di Indonesia dievaluasi pada tahun 2000, 2002, 2005, dan 2010. Menurut Kementerian Pendidikan dan Kebudayaan Direktorat Jenderal Pendidikan Dasar Direktorat Pembinaan Sekolah Dasar 2012 implementasi program MBS di Indonesia dievaluasi pada Tahun 2000, 2002, 2005, dan 2010. Hasil evaluasi pada Tahun 2000, 2002, 2005 menunjukkan bahwa program pembinaan MBS memberikan dampak positif, antara lain: (1) peningkatan manajemen sekolah yang lebih transparan, partisipatif, demokratis dan akuntabel; (2) peningkatan mutu pendidikan; (3) menurunnya tingkat putus sekolah; (4) peningkatan implementasi pembelajaran yang berpusat pada siswa dengan strategi PAKEM; dan (5) peningkatan peran serta mayarakat terhadap pendidikan di SD (Mistrianingsih, Imron dan Nurabadi, 2016).

Hasil evaluasi yang dilakukan oleh KEMENDIKBUD pada MBS disaat Unit Pelaksana Teknis (UPT) untuk Sekolah Dasar (SD) belum dihapus. Tugas dari UPT tersebut adalah membantu pihak sekolah dalam melakukan manajemen Pendidikan pada SD. Tahun 2018 UPT di hapus di Kabupaten Tangerang, hal ini pasti akan merubah 
beberapa pola dalam manajemen Pendidikan SD. Dari data penelitian diperoleh dari hasil angket, wawancara, dan diperkuat dengan dokumentasi yang dilakukan di Sekolah Dasar Kabupaten Tangerang. Subjek penelitian data angket teridiri dari kepala sekolah, wakil kepala sekolah, pengawas (K3S) dan perwakilan PGRI kecamatan yang berjumlah 55 responden. Data yang diambil merupakan informasi yang berkaitan dengan implementasi MBS di Sekolah Dasar di Kabupaten Tangerang yang meliputi kemandirian, kerjasama, partisipasi, keterbukaan, dan akuntabilitas sekolah. Berikut ini deskripsi data hasil penelitian:

Tabel 1.

Rerata Jumlah Skor Implementasi Manajemen Berbasis Sekolah

\begin{tabular}{|clcccc|}
\hline No & Variabel & Jumlah Item & Skor Min & Skor Maks & Skor \\
\hline 1 & Kemandirian Sekolah & 50 & 4.900 & 19.600 & 14.751 \\
\hline 2 & Kerjasama Sekolah & 12 & 1.176 & 4.704 & 3.496 \\
\hline 3 & Bentuk Partisipasi & 12 & 1.176 & 4.704 & 3.528 \\
\hline 4 & Keterbukaan Sekolah & 8 & 784 & 3.136 & 2.456 \\
\hline 5 & Akuntabilitas Sekolah & 6 & 588 & 2.352 & 1.753 \\
\hline & $\begin{array}{c}\text { Impelementasi MBS secara } \\
\text { keseluruhan }\end{array}$ & 88 & 8.624 & 34.496 & 25.984 \\
\hline
\end{tabular}

Sumber : Penulis 2020

Berdasarkan data Tabel 1, bahwa variable kemandirian sekolah mendapatkan skor paling tinggi dibandingkan dengan variable lainnya (Kerjasama sekolah, Bentuk Partisipasi, Keterbukaan Sekolah dan Akuntabilitas Sekolah).

Dari data diatas, maka rata-rata ideal (Mi) dan standar deviasi ideal (sdi) dapat dihitung. Selanjutnya dibuat kategori penilaian masing-masing variabel sesuai dengan rumus dari olah data. Berikut ini hasil pengkategoriannya.

Tabel 2.

Kategori Penilaian Jumlah Skor Implementasi Manajemen Berbasis Sekolah

\begin{tabular}{|c|c|c|c|c|}
\hline No & Variabel & Rentang Nilai & Skor & Kategori \\
\hline \multirow{4}{*}{1} & Kemandir & $=$ Sangat Baik & \multirow{4}{*}{14.751} & \multirow{4}{*}{ Baik } \\
\hline & $\begin{array}{l}\text { ian } \\
\text { Sekolah }\end{array}$ & $\begin{array}{l}13.475 \mathrm{~s} / \mathrm{d} 15.901=\text { Baik } \\
11.049,5 \mathrm{~s} / \mathrm{d} 13.451=\text { = Cukup Baik } \\
8.600 \mathrm{~s} / \mathrm{d} 11.025=\text { Kurang Baik }\end{array}$ & & \\
\hline & & $\mathrm{x} \leq 8.575 \quad=$ Tidak Baik & & \\
\hline & & $=$ Sangat Baik & & \\
\hline \multirow[t]{3}{*}{2} & $\begin{array}{l}\text { Kerjasam } \\
\text { a Sekolah }\end{array}$ & $\begin{array}{ll}3.234 \mathrm{~s} / \mathrm{d} 3.816 & =\text { Baik } \\
2.652 \mathrm{~s} / \mathrm{d} 3228 & =\text { Cukup Baik } \\
2.064 \mathrm{~s} / \mathrm{d} 2.646 & =\text { Kurang Baik }\end{array}$ & \multirow[t]{3}{*}{3.496} & \multirow[t]{3}{*}{ Baik } \\
\hline & & $=$ Tidak Baik & & \\
\hline & & $=$ Sangat Baik & & \\
\hline 3 & $\begin{array}{l}\text { Bentuk } \\
\text { Partisipasi }\end{array}$ & $\begin{array}{ll}3.234 \mathrm{~s} / \mathrm{d} 3.816 & =\text { Baik } \\
2.652 \mathrm{~s} / \mathrm{d} 3.228 & =\text { Cukup Baik } \\
2.064 \mathrm{~s} / \mathrm{d} 2.646 & =\text { Kurang Baik }\end{array}$ & 3.528 & Baik \\
\hline
\end{tabular}




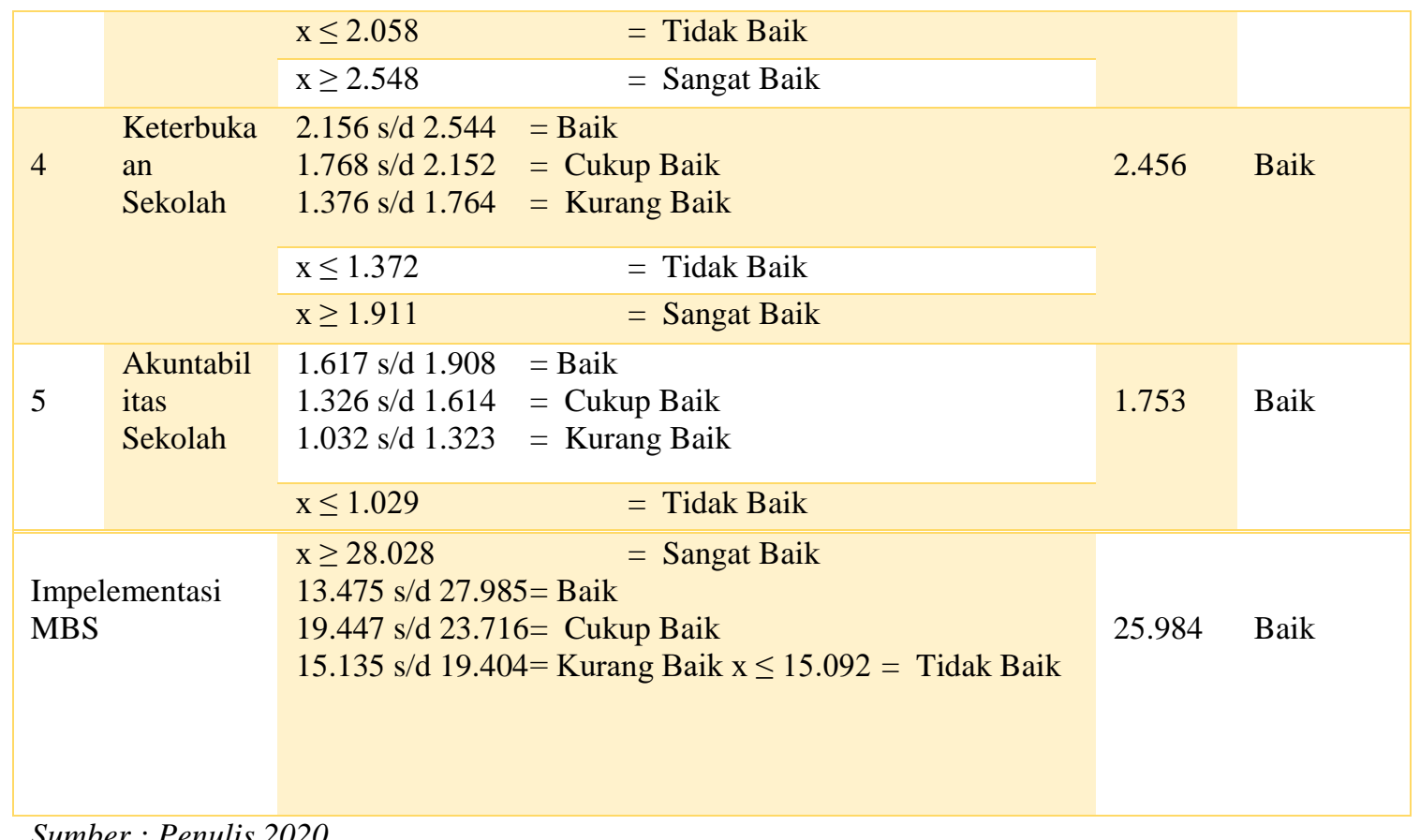

Sumber : Penulis 2020

Dari data Tabel 2 diatas dapat diketahui beberapa hal, pertama variable kemandirian sekolah mendapatkan skor paling tinggi yakni 14.751, yang artinya bahwa penerapan MBS telah menjadikan sekolah mandiri dan penghapusan Unit Pelaksana Tugas (UPT) pada Sekolah Dasar Negeri (SDN) kabupaten Tangerang tidak memiliki pengaruh terhadap manajemen Sekolah Dasar Negeri (SDN). Kedua, kerjasama sekolah juga memperoleh skor baik. Ini berarti bahwa rata-rata Sekolah Dasar Negeri (SDN) di kabupaten Tangerang memiliki pola kerjasama yang bagus baik dalam kerjasama tugas diinternal sekolah, atau pola kerjasama dengan pihak luar sekolah yang bertujuan membangun sekolah menjadi lebih baik.

Ketiga, variable Bentuk Partisipasi juga mendapatkan skor 3.528 yang artinya baik. Sehingga bisa disimpulkan bahwa partisipasi masyarakat di kabupaten Tangerang terhadap Sekolah Dasar Negeri (SDN) menunjukan bagus dalam kepedulian pada perjalan manajemen sekolah. Begitu juga sebaliknya, sekolah telah berperan baik dalam melibatkan masyarakat dalam membangun sekolahnya. Keempat, variable Keterbukaan. Walau skor pada variable ini adalah 1.753 tapi masuk kategori baik, jadi keterbukaan baik transparansi dana dan pendapat pada Sekolah Dasar Negeri (SDN) di Kabupaten Tangerang baik. Walaupun ada beberapa hal yang pihak sekolah tidak bisa terbuka dengan masyarakat karena adanya pertimbangan kebijakan internal yang harus ditutupi informasinya, hal ini sebagaimana peneliti dapatkan pada saat pengumpulan data. Sehingga tidak heran kalau skor pada variable ini rendah. Kelima, variable Akuntabilitas memiliki skor paling rendah dari variable lain, yaitu 1.753. akan tetapi variable ini dikategorikan baik. Artinya, akuntabilitas pada SDN di kabupaten Tangerang baik.

Berdasarkan perolehan jumlah skor diatas, bisa disimpulkan bahwa implementasi Manajemen Berbasis Sekolah pada kategori baik. Perolehan skor ini berasal dari perolehan jumlah skor tiap variabel. Variabel kemandirian sekolah, kerjasama sekolah, bentuk partisipasi, keterbukaan sekolah, dan akuntabilitas sekolah semuanya pada kategori baik. Berdasarkah hasil data ini maka dapat disimpulkan bahwa impelementasi manajemen berbasis sekolah di SD Kabupaten Tangerang dikategorikan baik pasca penghapusan UPT. Sisi lain, pemerintah tidak melakukan kesalahan dalam perubahan 
manajemen pada Sekolah Dasar Negeri (SDN) dalam bentuk penghapusan UPT pada tingkat bawah yang awalnya UPT menjadi jembatan antara Sekolah dan Dinas Pendidikan dalam konsultasi, pengawasan kebijakan dan anggaran. Sehingga ruh dari Pendidikan sebagai gerbang dalam membangun generasi bangsa yang memiliki megaskill dan mantap kedepannya masih terjaga dengan baik.

\section{CONCLUSION}

Sebagaimana harapan pemerintah bahwa Manajemen Berbasis Sekolah (MBS) adalah konsep dimana sekolah melakukan otonominya sendiri baik dalam pembangunan dan keuangan. Semua aspek bersifat demokrasi dan adanya keterlibatan masyarakat dalam pembangunan sekolah. Penghapusan Unit Pelaksana Tugas (UPT) pada Sekolah Dasar Negeri (SDN) di kabupaten Tangerang ternyat tidak memiliki pengaruh pada penerapan MBS. Yang awalnya sekolah memiliki ketergantungan pada UPT dalam hal konsultasi kebijakan dan keuangan, karena UPT adalah jembatan antara sekolah dan dinas pendidikan. Sehingga bisa disimpulkan bahwa penerapan MBS masih berjalan normal walau UPT telah dihapuskan dan kebijakan pemerintah akan penghapusan UPT tidak menjadikan pendidikan di SDN kabupaten Tangerang menurunkan mutunya. Rekomendasi untuk peneliti yang akan meneliti MBS adalah melakukan Analisa terkait lineritas akademik guru terhadap penerapan MBS, karena pada penilitian ini, peneliti tidak melakukan kajian akan hubungan lineritas akademik guru terhadap penerapan MBS.

\section{REFERENCES}

Arinda Firdianti. (2018). Implementasi Manajemen Berbasis Sekolah Dalam Meningkatkan Prestasi Belajar. Lampung: CV. GRE Publishing. Arinda Firdianti. (2018). Implementasi Manajemen Berbasis Sekolah Dalam Meningkatkan Prestasi Belajar. Lampung: CV. GRE Publishing.

Engkoswara dan Aan Komariah. (2015) . Administrasi Pendidikan. Bandung: Alfabeta.

Kemendikbud. (2013). Kerangka Dasar Kurikulum 2013. Jakarta: Kementerian Pendidikan dan Kebudayaan Direktorat Jenderal Pendidikan Dasar.

Mistrianingsih, S., Imron, A., \& Nurabadi, A. (2016). Peran Kepala Sekolah dalam Implementasi Manajemen Berbasis Sekolah. Jurnal Manajemen Pendidikan, Volume 25, Nomor 1. Hlm. 20-26.

Pratiwi, S. N. (2016). Manajemen Berbasis Sekolah dalam Meningkatkan Kualitas Sekolah. EduTech: Jurnal Ilmu Pendidikan Dan Ilmu Sosial, Vol. 2 No. 1 Hlm. 86-96.

Satori, Djam'an. (2016). Pengawasan dan Penjaminan Mutu Pendidikan. Alfabeta: Bandung. 